\title{
HUBUNGAN UMUR IBU DENGAN KEJADIAN PERSALINAN PREMATUR DI WILAYAH KERJA PUSKESMAS KALIANGKRIK KABUPATEN MAGELANG TAHUN 2012
}

\author{
Fatimah Sari ${ }^{1}$, Evy Ernawati ${ }^{2}$, Indartik ${ }^{3}$ \\ 1,2,3Program Studi D3 Kebidanan STIKes Guna Bangsa \\ fatimahsari.gunabangsa@gmail.com
}

\begin{abstract}
Background: One of the most common causes of death of neonates are low birth weight (LBW) either at term or preterm (premature). As a result of the premature births, children born will experience a variety of health problems due to lack of maturation of the fetus at birth which resulted in many organs of the body that have not been able to work perfectly. factors that can lead to preterm labor (preterm) or low birth weight infants is mother's first factor is less than 20 years of age or over 35 years .

Method: This study aims to determine the relationship between maternal age with the incidence of preterm labor.

Objective: This research is the type of observational analytic study with cross sectional approach. The sampling technique using saturated sample and the number of samples in this study were 75 respondents.

Result: The results showed no association with maternal age on the incidence of preterm labor Puskesmas Kaliangkrik Magelang Regency in 2012 with a p value of $0.000(0.000<$ 0.05 ) and the relationship is strong enough that the value of the Contingency Coefficient .431 .
\end{abstract}

Conclusion: There is a relationship with the mother's age incidence of preterm labor

Keywords : Mother age, Premature childbirth

\section{PENDAHULUAN}

Angka Kematian lbu (AKI) dan Angka kematian Bayi (AKB) senantiasa menjadi indikator keberhasilan pembangunan pada sektor kesehatan. AKI mengacu pada jumlah kematian ibu yang terkait dengan masa kehamilan, persalinan dan nifas, dan secara umum dari tahun ke tahun terjadi penurunan AKB. Kecenderungan penurunan AKB dapat dipengaruhi oleh pemerataan pelayanan kesehatan berikut fasilitasnya (Maryunani, 2009)

Berdasarkan Profil Kesehatan Indonesia 2008 (Depkes RI, 2009), hasil SDKI tahun 2007 menyebutkan bahwa AKI untuk periode 5 tahun sebelum survey (2003-2007) sebesar 228/100.000 kelahiran hidup. Angka ini turun dibandingkan AKI hasil SDKI tahun 2002-2003 yaitu mencapai 307/100.000 kelahiran hidup dan data dari Survei Demografi dan Kesehatan Indonesia (SDKI) tahun 2007 Angka Kematian Bayi (AKB) sebesar 34/1000 kelahiran hidup.

Salah satu penyebab kematian neonatus tersering adalah bayi berat lahir rendah (BBLR) baik cukup bulan maupun kurang bulan (prematur). Pertumbuhan dan perkembangan BBLR setelah lahir mungkin akan mendapat banyak hambatan. Perawatan setelah lahir diperlukan bayi untuk dapat mencapai pertumbuhan dan perkembangannya. Kemampuan ibu untuk memahami sinyal dan berespon terhadap bayi prematur berinteraksi dan memberikan dekapan (Widiyastuti dkk, 2009).

Persalinan preterm, terutama yang terjadi sebelum usia gestasi 34 minggu, menyebabkan $3 / 4$ dari keseluruhan 
mortalitas pada neonatus. Angka kematian bayi prematur dan sangat prematur (usia gestasi <32 minggu) lebih tinggi 15 dan 75 kali lipat dibandingkan dengan bayi yang lahir aterm. Bayi preterm yang bertahan hidup akan mengalami morbiditas serius jangka pendek, seperti sindrom distress pernapasan, displasia bronkopulmoner, perdarahan intraventrikuler, retinopati akibat prematuritas, dan jangka panjang, seperti gangguan perkembangan dan gangguan neurologis. Tingkat kelahiran preterm, kelahiran yang terjadi sebelum lengkap usia gestasi 37 minggu, di Amerika Serikat sekitar $12,3 \%$ dari keseluruhan 4 juta kelahiran setiap tahunnya, dan merupakan tingkat kelahiran preterm tertinggi di antara negara industry (Prasmusinto Dkk, 2010), sedangkan menurut Sungkar (2010) Di berbagai negara, angka kejadian persalinan preterm berkisar antara 5 $15 \%$, di

Indonesia sendiri kejadian persalinan preterm berkisar antara $10-20 \%$. Dan lebih dari $50 \%$ kasus persalinan preterm disebabkan oleh infeksi baik infeksi lokal maupun sistemik, yang mana untuk Indonesia, persalinan preterm ini disebabkan oleh infeksi baik infeksi lokal maupun sistemik, yang mana untuk Indonesia, persalinan preterm dapat menyebabkan $36 \%$ kematian neonatus. Persalinan prematur menjadi perhatian utama dalam bidang obstetrik karena erat kaitannya dengan morbiditas dan mortalitas perinatal dan persalinan prematur merupakan penyebab utama yaitu $60-80 \%$ morbiditas dan mortalitas neonatal di seluruh dunia (Suardana dkk, 2004). Angka kejadian kelahiran prematur yang masih tinggi yaitu di Amerika Serikat kejadiannya $8-10 \%$ dan di Indonesia kejadiannya $16-18 \%$ dari semua kelahiran hidup (Sastrawinata, 2005).

Kelahiran prematur bisa disebabkan karena adanya masalah kesehatan pada ibu hamil maupun pada janin itu sendiri yang merupakan faktor risiko dari terjadinya kelahiran prematur. Akibat dari kelahiran prematur tersebut, anak yang dilahirkan akan mengalami berbagai masalah kesehatan karena kurang matangnya janin ketika dilahirkan yang mengakibatkan banyaknya organ tubuh yang belum dapat bekerja secara sempurna. Hal ini mengakibatkan bayi prematur sulit menyesuikan diri dengan kehidupan luar rahim, sehingga mengalami banyak gangguan kesehatan (Musbikin, 2005). Selain berpengaruh terhadap pertumbuhan janin yang terhambat, persalinan prematur juga memberikan dampak yang negatif; tidak hanya kematian perinatal tetapi juga morbiditas perinatal, potensi generasi akan datang, kelainan mental dan beban ekonomi bagi keluarga dan bangsa secara keseluruhan (Rompas, 2004).

Beberapa faktor yang dapat menyebabkan terjadinya persalinan preterm (prematur) atau bayi berat lahir rendah adalah pertama faktor ibu meliputi; gizi saat hamil yang kurang, umur kurang dari 20 tahun atau diatas 35 tahun, jarak hamil dan bersalin terlalu dekat, penyakit menahun ibu, hipertensi, jantung gangguan pembuluh darah (perokok) dan faktor pekerja yang terlalu berat, kedua faktor kehamilan meliputi; hamil dengan hidramnion, hamil ganda, perdarahan antepartum, komplikasi hamil preeklampsia/eklampsia, ketuban pecah dini, ketiga faktor janin meliputi; cacat bawaan, infeksi dalam rahim, dan keempat faktor yang masih belum diketahui (Manuaba, 2012).

Bila kehamilan ini diteruskan dalam usia yang relatif muda dari sudut ilmu kebidanan dapat mengakibatkan penyulit (komplikasi) kehamilan yang cukup besar diantaranya persalinan belum cukup bulan (prematuritas), pertumbuhan janin dalam rahim yang kurang sempurna, kehamilan dengan keracunan yang memerlukan penanganan khusus, persalinan sering berlangsung dengan tindakan operasi, perdarahan setelah melahirkan makin meningkat, kembalinya alat reproduksi yang terlambat setelah persalinan, mudah terjadi infeksi setelah persalinan, pengeluaran ASI yang tidak cukup. Menurut Setyowati dalam Suriani (2010) risiko melahirkan bayi dengan BBLR pada ibu yang berusia kurang dari 20 tahun adalah 1,34 kali dibanding ibu yang berusia 20-35 tahun. Jumlah bayi berat lahir rendah (BBLR) di Jawa Tengah pada tahun 2011 sebanyak 21.184 meningkat 
banyak apabila dibandingkan tahun 2010 yang sebanyak 15.631. Adapun persentase BBLR tahun 2011 sebesar $3,73 \%$, meningkat bila dibandingkan tahun 2010 sebesar 2,69\% (Dinas Kesehatan Provinsi Jawa Tengah, 2012).

Jumlah kejadian persalinan prematur di Kabupaten Magelang pada tahun 2012 sebanyak 499 (5,15\%) dari 9679 persalinan yang ada (Dinas Kesehatan Kabupaten Magelang, 2012). Puskesmas Kaliangkrik merupakan salah satu sarana prasarana kesehatan yang berada di kecamatan Kaliangkrik Kabupaten Magelang dan mengampu 20 desa binaan. Di wilayah kerja Puskesmas Kaliangkrik masih banyak ibu hamil di usia yang berisiko terhadap kehamilan-nya. Berdasarkan data tahun 2012 dari 948 persalinan, sebanyak $37 \quad(3,9 \%)$ persalinan prematur (Laporan KIA Puskesmas Kaliangkrik, 2012).

\section{METODE PENELITIAN}

Jenis penelitian ini merupakan penelitian analitik observational dengan rancangan penelitian potong lintang (Cross sectional). Populasi pada penelitian ini adalah semua ibu bersalin prematur di wilayah kerja Puskesmas Kaliangkrik Kabupaten Magelang pada bulan Januari tahun 2011 s/d Desember 2012 sebanyak 75 ibu bersalin prematur. Sampel diambil mengambil sampel pada

kelompok kasus persalinan prematur. Teknik pengambilan sampel dengan menggunakan teknik cara sampling jenuh. Analisis data dilakukan dengan menggunakan perhitungan secara statistik. Metode statistik yang digunakan yaitu uji Chi Square $\left(x^{2}\right)$ untuk mengetahui ada tidaknya hubungan antar variabel yang diduga ada hubungan. Untuk mengetahui keeratan hubungan digunakan koefisien kontingen (CC).

\section{HASIL \& PEMBAHASAN}

\section{Umur lbu}

Hasil penelitian pada variabel umur ibu diperoleh data sebagian besar responden dalam kategori umur $<20$ dan $>35$ tahun yaitu sebanyak 43 (57,3\%) ibu bersalin (tabel 1).

Umur yang dipandang memiliki risiko saat melahirkan adalah di bawah 20 tahun dan di atas 35 tahun. Sedangkan antara 20-35 tahun dari segi usia risiko melahirkannya nol. Untuk yang usia di bawah 20 tahun, risiko kehamilannya karena alat-alat atau organ reproduksinya belum siap untuk menerima kehamilan dan melahirkan. Alat-alat reproduksi yang belum siap itu antara lain organ luar seperti liang vagina, bibir kemaluan, muara saluran kencing dan perinium (batas antara liang vagina dan anus) tidak siap untuk bekerja mendukung persalinan. Begitu pula halnya dengan organ dalam seperti rahim, saluran rahim dan indung telur. Wanita muda yang umurnya di bawah 20 tahun terhitung masih dalam proses pertumbuhan. Memang mereka sudah mendapatkan haid (menstruasi), namun sebenarnya bukan berarti organ reproduksinya sudah matang seratus persen. Sedangkan untuk wanita dewasa berusia lebih dari 35 tahun ke atas, kondisi organ-organ reproduksinya berbanding terbalik dengan yang di bawah 20 tahun. Pada usia itu wanita mulai mengalami proses penuaan. Dengan kondisi seperti itu maka terjadi regresi atau kemunduran dimana alat reproduksi tidak sebagus layaknya normal, sehingga sangat berpengaruh pada penerimaan kehamilan dan proses melahirkan (Emon, 2007).

Tabel 1. Distribusi frekuensi umur ibu bersalin di wilayah kerja Puskesmas Kaliangkrik Kabupaten Magelang tahun 2012

\begin{tabular}{lll} 
No & Kategori & Frekuensi \\
\hline 1 & Umur $20-35$ tahun & $32(42,7 \%)$ \\
2 & Umur $<20$ dan $>35$ tahun & $43(57,3 \%)$ \\
\hline & Jumlah & $75(100 \%)$
\end{tabular}




\section{Kejadian Persalinan Prematur}

Berdasarkan hasil tabulasi data pada variabel kejadian persalinan prematur diperoleh data sebagian besar responden mengalami kejadian persalinan prematur yaitu sebanyak 54 (72\%) ibu bersalin (tabel 2), sehingga dapat disimpulkan persalinan terjadi pada usia kehamilan 32 -36 minggu.

Persalinan preterm, terutama yang terjadi sebelum usia gestasi 34 minggu, menyebabkan $3 / 4$ dari keseluruhan mortalitas pada neonatus. Angka kematian bayi prematur dan sangat prematur (usia gestasi <32 minggu) lebih tinggi 15 dan 75 kali lipat dibandingkan dengan bayi yang lahir aterm. Bayi preterm yang bertahan hidup akan mengalami morbiditas serius jangka pendek, seperti sindrom distress pernapasan, displasia bronkopulmoner, perdarahan intraventrikuler, retinopati akibat prematuritas, dan jangka panjang, seperti gangguan perkembangan dan gangguan neurologis.

Tingkat kelahiran preterm, kelahiran yang terjadi sebelum lengkap usia gestasi 37 minggu, di Amerika Serikat sekitar $12,3 \%$ dari keseluruhan 4 juta kelahiran setiap tahunnya, dan merupakan tingkat kelahiran preterm tertinggi di antara negara industry (Prasmusinto Dkk, 2010).
Hubungan umur ibu dengan kejadian persalinan prematur di wilayah kerja Puskesmas Kaliangkrik Kabupaten Magelang tahun 2012

Hasil tabulasi silang hubungan umur ibu dengan kejadian persalinan prematur di wilayah kerja Puskesmas Kaliangkrik Kabupaten Magelang tahun 2012 diperoleh hasil dari 32 ibu bersalin dengan umur 20-35 tahun, sebagian besar mengalami persalinan prematur yaitu sebanyak 31 (96,9\%), sedangkan dari 43 ibu bersalin dengan umur $<20$ dan $>35$ tahun sebagian besar mengalami persalinan prematur yaitu sebanyak 23 $(53,5 \%)$ ibu bersalin (tabel 3$)$, sedangkan hasil hitung hubungan umur ibu dengan kejadian persalinan prematur dengan menggunakan uji Chi Square Test didapatkan $x^{2}$ hitung sebesar 17,131 maka $17,131>5,991\left(x^{2}\right.$ tabel) dan $p$ value 0,000 , sehingga ada hubungan umur ibu dengan kejadian persalinan prematur di wilayah kerja Puskesmas Kaliangkrik Kabupaten Magelang tahun 2012, sedangkan untuk mengetahui keeratan hubungan umur ibu dengan kejadian persalinan prematur terlihat pada Contingency Coefficient adalah 0,431 dan hubungan tersebut cukup kuat karena nilainya berada pada rentang $0,30-0,49$.

Umur reproduksi aman untuk melahirkan dan persalinan adalah umur 20-30

Tabel 2. Distribusi frekuensi kejadian persalinan prematur pada ibu bersalin yang berusia risiko di wilayah kerja Puskesmas Kaliangkrik Kabupaten Magelang tahun 2012

\begin{tabular}{cll} 
No & Kategori & Frekuensi \\
\hline 1 & Persalinan Prematur & $54(72 \%)$ \\
2 & Persalinan Sangat Prematur & $21(28 \%)$ \\
\hline & Jumlah & $75(100 \%)$
\end{tabular}

Tabel 3. Tabulasi silang hubungan umur ibu dengan kejadian persalinan prematur di wilayah kerja Puskesmas Kaliangkrik Kabupaten Magelang tahun 2012

\begin{tabular}{|c|c|c|c|c|c|c|c|c|c|c|}
\hline \multirow{2}{*}{$\begin{array}{l}\text { Umur lbu } \\
\text { (tahun) }\end{array}$} & \multicolumn{2}{|c|}{ Prematur } & \multicolumn{2}{|c|}{$\begin{array}{l}\text { Sangat } \\
\text { Prematur }\end{array}$} & \multicolumn{2}{|c|}{$\begin{array}{l}\text { Ekstrim } \\
\text { Prematur }\end{array}$} & \multicolumn{2}{|c|}{ Jumlah } & \multirow{2}{*}{$\begin{array}{c}x^{2} \\
\text { hitung }\end{array}$} & \multirow{2}{*}{$\begin{array}{c}\mathrm{p} \\
\text { value }\end{array}$} \\
\hline & $f$ & $\%$ & $f$ & $\%$ & $f$ & $\%$ & $f$ & $\%$ & & \\
\hline $20-25$ & 31 & 96,9 & 1 & 0,01 & 0 & 0 & 32 & 100 & \multirow{2}{*}{17,131} & \multirow{2}{*}{0,000} \\
\hline$<20$ dan $>35$ & 23 & 53,5 & 20 & 46,5 & 0 & 0 & 43 & 100 & & \\
\hline
\end{tabular}


tahun, umur dibawah dan diatas usia tersebut dapat meningkatkan faktor resiko dalam kehamilan dan persalinan. Kematian maternal pada ibu yang berusia muda (< 20 tahun) 2-5 kali lebih tinggi daripada usia 20-29 tahun dan kematian tersebut akan meningkat kembali sesudah usia 35 tahun (Wiknjosastro, 2009).

Usia di bawah 20 tahun dapat menjadi penyebab risiko tinggi pada waktu hamil dan melahirkan, hal ini karena pada usia di bawah 20 tahun alat-alat reproduksi seorang wanita belum cukup matang untuk dibuahi sehingga terjadi keguguran, perdarahan selama kehamilan, sedangkan pada usia diatas 35 tahun juga dapat menjadi penyebab terjadinya risiko tinggi pada waktu hamil dan melahirkan karena pada usia ini organ-organ reproduksi wanita sudah kaku atau tidak elastis lagi sehingga dapat menimbulkan kesulitan dalam persalinan dan dapat menyebabkan kematian pada seorang ibu (Husain,2008).

Pada usia lebih dari 35 tahun terjadi banyak problem kesehatan seperti hipertensi, diabetes mellitus, anemia, penyakit kronis lain serta terjadi cacat bawaan atau kelainan genetik (Hartanto, 2004). Pada usia diatas 35 tahun peningkatan risiko hipertensi kronik, kehamilan ektopik, persalinan yang lama pada nulipara, Sectio Caesarea, kelahiran premature, IUGR, abnormalitas kromosom, kematian janin (Varney, 2002)

Hasil penelitian ini tidak sejalan dengan hasil penelitian Alvonso (2011) yaitu bayi prematur terbanyak pada ibu dengan umur 20-35 tahun (88,9\%) yang artinya persalinan prematur terjadi pada ibu dengan umur reproduksi sehat. Beberapa faktor yang dapat menyebabkan terjadinya persalinan preterm (prematur) atau bayi berat lahir rendah menurut Manuaba (2012) adalah pertama faktor ibu meliputi; gizi saat hamil yang kurang, umur kurang dari 20 tahun atau diatas 35 tahun, jarak hamil dan bersalin terlalu dekat, penyakit menahun ibu, hipertensi, jantung gangguan pembuluh darah (perokok) dan faktor pekerja yang terlalu berat, kedua faktor kehamilan meliputi; hamil dengan hidramnion, hamil ganda, perdarahan antepartum, komplikasi hamil: preeklampsia/eklampsia, ketuban pecah dini, ketiga faktor janin meliputi; cacat bawaan, infeksi dalam rahim, dan keempat faktor yang masih belum diketahui, selain berpengaruh pada penerimaan kehamilan dan proses melahirkan, kehamilan pada usia kurang dari 20 tahun dan di atas 35 tahun juga berisiko untuk melahirkan bayi prematur.

Faktor predisposisi terjadinya kelahiran prematur di antaranya: (a) faktor ibu, riwayat kelahiran prematur sebelumnya, perdarahan antepartum, malnutrisi, kelainan uterus, hidromion, penyakit jantung/penyakit kronik lainnya, hipertensi, umur ibu kurang dari 20 tahun atau lebih dari 35 tahun, jarak dua kehamilan yang terlalu dekat, infeksi, trauma, kebiasaan, yaitu pekerjaan yang melelahkan, merokok; (b) faktor janin, cacat bawaan, kehamilan ganda, hidramion, ketuban pecah dini; (c) keadaan sosial ekonomi yang rendah (Prawirohardjo, 2006)

\section{KESIMPULAN DAN SARAN}

Berdasarkan hasil penelitian hubungan umur ibu dengan kejadian persalinan prematur di wilayah kerja Puskesmas Kaliangkrik Kabupaten Magelang tahun 2012 maka peneliti menyimpulkan:

1. Ibu bersalin pada kategori umur $<20$ dan > 35 tahun ada 43 (57,3\%)

2. Ibu bersalin mengalami persalinan prematur ada 54 (72\%)

3. Ada hubungan umur ibu dengan kejadian persalinan prematur di wilayah kerja Puskesmas Kaliangkrik Kabupaten Magelang tahun 2012 dengan $p$ value $0,000(0,000<0,05)$ dan hubungan tersebut cukup kuat karena nilai Contingency Coefficient 0,431 .

\section{DAFTAR PUSTAKA}

Agustina, F, 2006. Aplikasi Uji Kai kuadrat Mantel Haenszel dan Uji Regresi Logistik Ganda Untuk Penilaian Peranan Variabel Perancu Pada Hubungan Antara Paritas dengan Partus Prematur (Studi di RSU dr. Soetomo Surabaya. [Diakses tanggal : 20 Oktober 2013]. Diambil 
dari:

http://www.adln.lib.unair.ac.id/go.ph

p?id=gdlhub-gdl-s1-2006-

agustinafi2479\&width $=300 \&$ PHPSE

SSID $=068$ ef00626d3e335b599

98cc35e21ce4, diakses 16

September 2008.

Alvonso. (2011). Gambaran Karakteristik Ibu Yang Melahirkan Bayi Prematur di RSUP $H$ Adam Malik Medan Tahun 2007. [Diakses tanggal : 20 Oktober 2013]. Diambil dari: http://repository.usu.ac.id/simplesear ch?query=\&submit. $x=17 \&$ submit. $y=$ 11.

Ariani. (2011). Hubungan Preeklampsia dengan Berat Bayi Lahir Rendah di RSUP H. Adam Malik Medan Tahun 2009. [Diakses tanggal : 20 Oktober 2013]. Diambil dari: http://repository.usu.ac.id/simplesear ch?query=\&submit. $x=17 \&$ submit. $y=$ 11.

Behrman, R. E., Kliegman, R. dan Arvin, A. M., 2000. IImu Kesehatan Anak. Volume 1. Jakarta: EGC. Budiarto, E. 2002. Biostatistika untuk kedokteran dan Kesehatan Masyarakat. Jakarta : EGC.

Budayasa, dkk, 2006. Peranan Faktor Risiko Ketuban Pecah Dini Terhadap Insidens Sepsis Neonatorum Dini Pada Kehamilan Aterm. [Diakses tanggal : 20 Oktober 2013]. Diambil dari: http://www.kalbe.co.id/files/cdk/files/ 08 151_PerananFaktorRisikoKetub anPecah.pdf/08_151_PerananFakto rRisikoKetubanPecah.pdf.

Depkes RI. 2009. Profil Kesehatan Indonesia 2008. Jakarta : Depkes RI.

Dinas Kesehatan Provinsi Jawa Tengah. 2012. Profil Kesehatan Jawa Tengah Tahun 2012. Semarang; Dinkes Jateng.

Emon, 2007. Persalinan Berisiko Sebabkan Kematian. [Diakses tanggal :20
Oktober 2013]. Diambil dari: http://pikas.bkkbn.go.id/news_detail. php?nid=5590.

Hartanto. 2004. Keluarga Berencana dan Kontrasepsi. Jakarta : Pustaka Sinar Harapan.

Hidayat. 2010. Metode Penelitian Kebidanan dan Teknik Analisis Data.Jakarta : Salemba Medika 